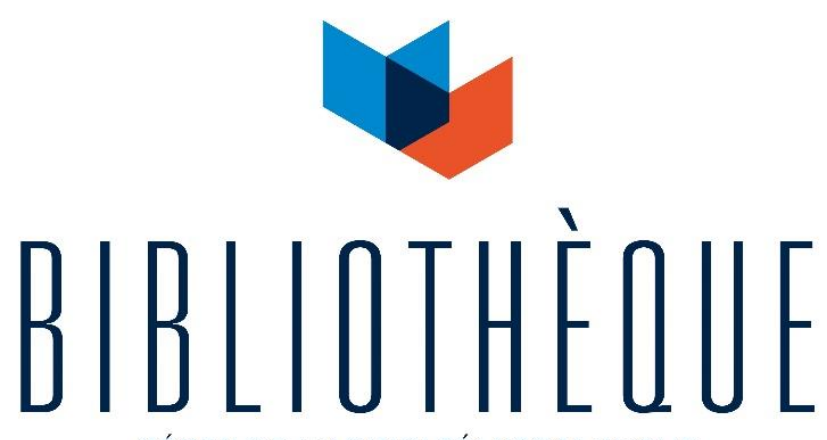

CÉGEP DE L'ABITIBI-TÉMISCAMINGUE

UNIVERSITÉ DU QUÉBEC EN ABITIBI-TÉMISCAMINGUE

\title{
Mise en garde
}

La bibliothèque du Cégep de l'Abitibi-Témiscamingue et de l'Université du Québec en Abitibi-Témiscamingue (UQAT) a obtenu l'autorisation de l'auteur de ce document afin de diffuser, dans un but non lucratif, une copie de son œuvre dans Depositum, site d'archives numériques, gratuit et accessible à tous. L'auteur conserve néanmoins ses droits de propriété intellectuelle, dont son droit d'auteur, sur cette œuvre.

\section{Warning}

The library of the Cégep de l'Abitibi-Témiscamingue and the Université du Québec en Abitibi-Témiscamingue (UQAT) obtained the permission of the author to use a copy of this document for nonprofit purposes in order to put it in the open archives Depositum, which is free and accessible to all. The author retains ownership of the copyright on this document. 


\section{Salesforce Responsive Roles in Turbulent Times: Case Studies in Agility Selling}

\section{Introduction}

The nature and complexity of business-to-business (B2B) sales has grown (Schmitz and Ganesan, 2014). Salesforces are required to be ambidextrous and adjust to the selling context (Mullins, Agnihotri and Hall, 2020). The external environment is also creating new challenges as Geersbro \& Ritter (2010) note. Uncertainty and ambiguity are amplified due to economic pace and the reach of international sales networks, which accelerate the disruptive effect of critical events and their turbulence. Critical events refer to incidents that lead to radical changes in business dyads or networks (Halinen, Salmi and Havila, 1999; Havila and Salmi, 2000) and have been used to explain negative disruptions in customer relationships (Edvardsson and Strandvik, 2000; Edvardsson et al., 2014) and business relationships (Edvardsson et al., 2014). Critical events in B2B have been the result of economic and trade changes, critical material shortages, and more recently, the onslaught of a global pandemic, all of which have abruptly forced sales organizations to be capable of managing uncertainty (Hartmann and Lussier, 2020; Sharma et al., 2020) and demonstrate agile principles (Mora Cortez and Johnston, 2020).

The complexity and challenging environment of B2B sales requires an ability for the salesforce to adjust quickly. The terms "agile" and "agility" are frequently used in the management literature including supply chain management (Christopher, 2000; Tarafdar and Qrunfleh, 2017), manufacturing (Yusuf, Sarhadi and Gunasekaran, 1999; Zhang and Sharifi, 2000; Gunasekaran et al., 2019), service infusion (Kowalkowski et al., 2012), and marketing 
(Zhou, Mavondo and Saunders, 2019). In sales, Chonko \& Jones (2005) define agility selling's core abilities along two dimensions: responsiveness and focus on opportunities.

However, a deeper review of the literature finds that beyond the work of Chonko and Jones, agility has not yet gained traction within B2B sales and sales management even though they prophetically suggest that in "turbulent business times" (p.371), a salesperson should demonstrate agility selling to increase an organization's responsiveness. Likewise, this underexploited concept of agility selling is increasingly relevant in the turbulent nature of the B2B global supply chain. Unfortunately, empirical research on the responsive role of the salesforce has been noticeably absent from the literature as has been its role on agility selling (Gias, 2016). We contend that agility selling should not only be placed on a higher research agenda, but also incorporated into practice, by having salespeople proactively manage turbulence through increased responsiveness.

A comprehensive review demonstrates that the research on agility in B2B selling and sales management is sparse. Various key gaps have been identified. First, clarity with regard to the linkage between critical events and their resulting turbulence is limited which adds more ambiguity to our understanding both theoretically and in practice. Second, although Chonko and Jones (2005) propose agility to the sales literature, the details of agility selling's unique processes and as a distinct sales behavior have unfortunately not been fully developed in the interim. Lastly, a clear outlook on the potential impact of agility selling on research and practice is absent thus leaving a gap in our understanding of the effects and implications of higher levels of responsiveness in the salesforce. 
This study aims to address these gaps and accomplish three specific objectives. First, and most importantly, to demonstrate in practice how the sales force responds to turbulence; second, to expand the original conceptual framework of agility selling by bringing into light the agile sales force's ability for forecasting; third, to contribute to agility selling and hopefully rekindle interest in this much needed field of research where no empirical research has yet been performed.

The paper is divided into six sections. Following this introduction, the next section reviews the literature and defines several important related concepts, namely critical events, turbulence, and agility selling. It also offers a systematic literature review of agility selling. The third section describes the collaborative autoethnographic approach, which was based on data from in-depth interviews with key salespeople involved in turbulent environments and resulted in the eight case studies that are included in the results section. These case studies help build the framework of the four categories of responsiveness presented in the next section, which also discusses the study's implications, both theoretical and managerial. The paper then concludes with its limitations and future research opportunities.

\section{Literature Review}

This section defines critical events and provides examples of the subsequent turbulence they generate. It also explains agility selling in the salesforce, based on Chonko and Jones (2005). The main idea that ties it all together is that a critical event is the source of the turbulence that an agile salesperson deals with to add value to the customer-supplier dyad. A review of 
current research on agility selling is then presented with an emphasis on the gaps that should be addressed.

\subsection{Critical events and turbulence}

Critical events are events "that give birth to change" (Halinen et al., 2013, p.1218). They can provoke drastic changes in a relationship (Halinen, Salmi and Havila, 1999), redefine it (Schurr, Hedaa and Geersbro, 2008) or be the cause of its dissolution (Tähtinen and Halinen, 2000). They can explain how a cooperative relationship can shift to a competitive one (Tidström and Hagberg-Andersson, 2012). Critical events are different from regular business problems that are familiar to salespeople. Regular business problems include defective products, delayed deliveries, or price negotiations. However, these regular business problems can become critical events when they experience an out of the ordinary increase in number or in magnitude. For example, a 24-hour delivery delay might be a regular business problem whereas a delivery delay of a few days could be a critical event. Negotiating the price on a single delivery might qualify as a regular business problem whereas negotiating the price on the total yearly amount of products or services bought by a large client might be considered a critical event. Because critical sales events can impact salespeople's performance, Russ et al. (1998) recommend that sales managers help their salespeople to cope with negative critical sales events, such as the loss of a customer. Turbulence is the propagating effect of a critical event (Edvardsson et al., 2014).

The Covid-19 pandemic is, in itself, an exceptional critical event that exemplifies the need for an agile approach where developing the ability to predict critical events, when possible, is highly recommended (Mora Cortez and Johnston, 2020). Likewise, in regards to the COVID19 pandemic, Hartmann and Lussier (2020) explain that its direct impact (i.e. critical event) can 
create additional impact (i.e. turbulence) that call for specific (i.e. agile) responses from salespeople. They argue that these times of change create opportunities to strengthen relationships.

Turbulence can be felt at different levels. At the market level, the implementation of improved communication technologies represents a critical event that has globalized supply chains (Steinle, Schiele and Ernst, 2014), globalized outsourcing (Strandvik, Holmlund and Edvardsson, 2012), and reduced the supply base through reverse electronic auctions (Boeck, Bendavid and Lefebvre, 2009). At the network level, mergers and acquisitions can cause radical change by turning previous competitors into collaborators and affect their surrounding companies (Havila and Salmi, 2000). At the dyad level, a critical event can trigger turbulence in a relationship (Halinen, Salmi and Havila, 1999; Elo, Halinen and Törnroos, 2010), for instance when a customer threatens its supplier in order to drastically modify payment terms or to receive a bribe (Bourguignon, Boeck and Clarke, 2020). Critical events such as an important cost increase, a production facility relocation, or a new product launch are other critical events that can generate enough turbulence to affect trading partners. Critical events can also give rise to turbulence that is localized within an individual firm. For example, the survivor syndrome documents a situation where a psychological "malaise" persists among remaining employees following an excessive downsizing event (Appelbaum et al., 1997). Turbulence encourages managers to align the sales process with the business strategy (Piercy, 2010), especially where there is a "need for speed" (Ojha et al., 2020), while taking advantage of opportunities (Chu, Chang and Huang, 2012). 


\subsection{Agility selling: a distinct sales behavior}

In response to turbulence the salesforce needs to be agile. It must anticipate turbulence and respond to it as it is responsible for maintaining the quality of customer relationships despite this turbulence (Jones et al., 2005). According to Chonko \& Jones, 2005 (p.372), salesforce agility selling involves two main abilities:

1. Respond to changes quickly and adequately: An agile salesforce plays an active role in the face of turbulence. In addition to being very nimble, it responds rapidly to the unanticipated. A very distinct and central concept in the original article was speed, not only "speed of action," but the speed used to adapt to the unexpected (Chonko and Jones, 2005), which can become a decisive factor. Of course, speed just for the sake of speed is inefficient; if actions are to be taken then the agile salesforce executes them efficiently and adequately.

2. Exploit changes as opportunities: Change can be considered a problem for the nonagile salesperson. Conversely, an agile salesforce thrives under conditions of change and turbulence. They take advantage of them and perceive them to be opportunities. Agile "salespeople and sales organizations are willing to consider new evidence, change direction, and consider adjustments to strategy, offering new value propositions in light of new or anticipated customer developments" (Chonko \& Jones, 2011, p.2).

\subsection{Agility selling represents an untapped research opportunity}

Research on agility selling represents a vastly unexploited field and an opportunity for academicians because very little research has been done on the topic. Indeed, searches in EBSCO 
Information Services and ABI/Inform databases reveal that surprisingly only twenty-four peerreviewed articles have so far cited Chonko \& Jones (2005) seminal article and each of them use fewer than 200 words to discuss agility selling or its concepts. Table 1 presents the literature in chronological order. The quotes summarize the teachings from Chonko and Jones's article that were used in the articles. The articles can be divided into 4 categories. In the first category, seven articles explicitly recognize agility selling as a distinct sales behavior model. Ulaga \& Loveland (2014) and Viio \& Nordin (2017) recognize agility selling as a new and alternative sales behavior while others recognize the importance of speed (e.g., Haas et al., 2012). Terho et al. (2012) and others describe agility selling as an ability to uncover sales opportunities. Bonney et al. (2014) mention the importance of sensing and responding and, with Bachrach et al. (2017), add that the ability of shifting resources is also a characteristic of agility selling. Bolander et al. (2017) believe that agility can be developed over time through experiencing a turbulent environment. In summary, agility selling comprises distinct characteristics.

Eight other articles that refer to the concept of agility selling without mentioning it per se form the second category. The agility selling themes that had the most occurrence were those of change and turbulence, which were referenced by all authors in this category except for one; followed by speed (e.g., Mulki et al., 2008), the importance of organizational support and resources (e.g., Matanda \& Ewing, 2012), responsiveness (Johnson and Sohi, 2017), and innovativeness (Lassk and Shepherd, 2013).

Five articles form a third category and use the seminal article in reference to other sales behavior models, thereby ignoring agility selling altogether. This was most often in regards to the "distinct but related concept of adaptive selling" (Bolander et al., 2017,p.166). Chonko and 
Jones took great care in distinguishing agility selling from adaptive selling. Adaptive selling suggests a sales technique where a specific salesperson aligns sales behavior during customer interactions to be better attuned with the selling situation and to increase sales performance (Weitz, Sujan and Sujan, 1986; Spiro and Weitz, 1990; Singh and Das, 2013). Agility selling is adapting to the changes to the environment not changes in the sales pitch.

The last category consists of four articles that reference Chonko and Jones' article to illustrate workforce agility in general and not specifically in sales.

Table 1: Agility Selling inspired research 


\begin{tabular}{|c|c|c|}
\hline Authors & Cat & How Chonko and Jones' article is referenced \\
\hline $\begin{array}{l}\text { Mulki, Lassk, \& } \\
\text { Jaramillo, 2008, p.283 }\end{array}$ & 2 & $\begin{array}{l}\text { To be successful, salespeople must quickly identify opportunities and predict the changing needs and wants } \\
\text { of customers (Chonko and Jones 2005) }\end{array}$ \\
\hline $\begin{array}{l}\text { Bonney \& Williams, } \\
2009, \text { p.1034-1035 }\end{array}$ & 3 & $\begin{array}{l}\text { Salespeople [must] become adept resource managers in addition to their traditional roles of persuasion and } \\
\text { promotion (Chonko and Jones, 2005) }\end{array}$ \\
\hline Aspara, 2011, p.271 & 2 & Organization-wide agility [can help] deal with $[. .$.$] turbulence$ \\
\hline $\begin{array}{l}\text { Terho, Haas, Eggert, \& } \\
\text { Ulaga, 2012, p.176 }\end{array}$ & 1 & $\begin{array}{l}\text { [Agility selling maintains] customer relationships through swift and appropriate responses to changes, and } \\
\text { exploiting changes as opportunities }\end{array}$ \\
\hline $\begin{array}{l}\text { Haas, Snehota, \& } \\
\text { Corsaro, 2012, p.102 }\end{array}$ & 1 & $\begin{array}{l}\text { Agility selling (Chonko \& Jones, 2005) [...] contribute[s] to managing emergent situations. Indeed these } \\
\text { suggest beneficial effects of the altering of the sales behavior, fast responses to customer's needs [...] }\end{array}$ \\
\hline $\begin{array}{l}\text { Matanda \& Ewing, 2012, } \\
\text { p.10 }\end{array}$ & 2 & $\begin{array}{l}\text { Agility, after all, means having the organizational support, resources, and intellectual capital necessary to } \\
\text { deal with change (Chonko \& Jones, 2005) }\end{array}$ \\
\hline $\begin{array}{l}\text { Lassk \& Shepherd, 2013, } \\
\text { p. } 25\end{array}$ & 2 & $\begin{array}{l}\text { Individual and organizational success depends on supplying innovative and useful solutions for customers in } \\
\text { a turbulent environment (Chonko and Jones 2005) }\end{array}$ \\
\hline Muduli 2013, p.60 & 4 & $\begin{array}{l}\text { Culture, collaboration, Information Systems and competencies are the major factors promoting agility in an } \\
\text { organization }\end{array}$ \\
\hline $\begin{array}{l}\text { Goad \& Jaramillo, 2014, } \\
\text { p.289 }\end{array}$ & 3 & $\begin{array}{l}\text { Adaptive selling can be conceptualized as a proactive process that salespeople utilize to increase their } \\
\text { performance. Adaptive selling is a developed skill that enables salespeople to assess customers' wants/needs } \\
\text { and then respond quickly and accurately to increasing customer demand (Chonko and Jones 2005) }\end{array}$ \\
\hline $\begin{array}{l}\text { Ulaga \& Loveland, 2014, } \\
\text { p.114 }\end{array}$ & 1 & [Agility selling is] a new sales approach[...] and selling behavior \\
\hline $\begin{array}{l}\text { L. Bonney, Plouffe, \& } \\
\text { Wolter, 2014, p. } 827\end{array}$ & 1 & $\begin{array}{l}\text { Sales rep agility }[\ldots] \text { stress[es] that reps need enough cognitive awareness to know when to shift resources } \\
\text { between different accounts and sales opportunities across their respective portfolios. }\end{array}$ \\
\hline $\begin{array}{l}\text { Alavi, Abd. Wahab, } \\
\text { Muhamad, \& Arbab } \\
\text { Shirani, 2014, p.1 }\end{array}$ & 4 & $\begin{array}{l}\text { A firm cannot become agile without properly addressing workforce agility in its agility programme or if the } \\
\text { workers are not agile (Chonko and Jones 2005) }\end{array}$ \\
\hline $\begin{array}{l}\text { Chen \& Jaramillo, 2014, } \\
\text { p.34 }\end{array}$ & 3 & $\begin{array}{l}\text { Salespeople assess customers' needs/wants and respond precisely and quickly in order to increase customer } \\
\text { demand }\end{array}$ \\
\hline $\begin{array}{l}\text { Bolander, Dugan, \& } \\
\text { Jones, 2017, p.166 }\end{array}$ & 1 & $\begin{array}{l}\text { [“Agility selling" is] a distinct, yet related, concept [to adaptive selling] describe[d as] a salesperson's ability } \\
\text { to "anticipate and identify problems and opportunities, consider and discuss alternatives with the customer, } \\
\text { and proffer successful solutions in real time." [...] Agile salespeople develop their abilities over time }[\ldots] \text {; is } \\
\text { perhaps predicated on having the requisite skills that perhaps only ongoing (i.e., repetitive) experience in a } \\
\text { turbulent environment may bring. }\end{array}$ \\
\hline $\begin{array}{l}\text { Viio \& Nordin, 2017, } \\
\text { p.123 }\end{array}$ & 1 & $\begin{array}{l}\text { Sales is nowadays more often considered as satisfying demand and cocreating value, rather than merely } \\
\text { stimulating demand (Haas, Snehota, and Corsaro 2012). Accordingly, a number of alternative selling } \\
\text { behaviors have also emerged in the literature [...] including agility selling (Chonko and Jones 2005) [...] }\end{array}$ \\
\hline Oh, 2017, p.1137 & 2 & $\begin{array}{l}\text { Speed (Chonko and Jones, 2005) [and other capabilities] may not any longer be their core competencies to be } \\
\text { competitive. [...] as the environment around individual salespeople changes, qualifications and prerequisites } \\
\text { change, as do salespeople's roles. That is, salesperson role change is an outcome of individual appraisal of } \\
\text { environmental change." }\end{array}$ \\
\hline $\begin{array}{l}\text { Johnson \& Sohi, 2017, } \\
\text { p.138 }\end{array}$ & 2 & $\begin{array}{l}\text { Salespeople represent the front line of implementation and are the face of the organization to the customer, } \\
\text { their responsiveness to strategies is of paramount importance and has been noted as an important driver of } \\
\text { customer and organizational outcomes (Chonko \& Jones, 2005) }\end{array}$ \\
\hline $\begin{array}{l}\text { Bachrach, Mullins, \& } \\
\text { Rapp, 2017, p. } 88\end{array}$ & 1 & $\begin{array}{l}\text { Th[e] added emphasis on customer sensing and responsiveness has shifted the salesperson activities and } \\
\text { resources necessary to compete at the salesperson-customer interface }\end{array}$ \\
\hline $\begin{array}{l}\text { Hossain \& Chonko, } \\
\text { 2018, p.231 }\end{array}$ & 3 & $\begin{array}{l}\text { It will be interesting to study how salesperson specific behaviors such as adaptive selling (Chonko \& Jones, } \\
\text { 2005; Wong, Liu, \& Tjosvold, 2015) differentially affect [loyalty] }\end{array}$ \\
\hline $\begin{array}{l}\text { Doeze Jager-van Vliet, } \\
\text { Born, \& van der Molen, } \\
2019, \text { p.42 }\end{array}$ & 4 & The development of adaptive and proactive agility by means of goal setting \\
\hline $\begin{array}{l}\text { Carballo-Penela, Varela, } \\
\& \text { Bande, 2019, p.366 }\end{array}$ & 2 & Salespeople must be able to quickly identify the changing needs and desires of customers \\
\hline $\begin{array}{l}\text { Micevski, Dewsnap, } \\
\text { Cadogan, Kadic- } \\
\text { Maglajlic, \& Boso, 2019, } \\
\text { p.552 }\end{array}$ & 2 & $\begin{array}{l}\text { In dynamic contemporary business environments, sales units are faced with heightened variation and } \\
\text { diversity in customer demands and competitor activity that require greater levels of internal collaboration and } \\
\text { flexibility in sales unit resources and procedures }\end{array}$ \\
\hline $\begin{array}{l}\text { Harindranath, } \\
\text { Bharadhwaj, \& Jacob, } \\
2019, \text { p. } 1725\end{array}$ & 3 & $\begin{array}{l}\text { Adaptive selling }[\ldots] \text { can improve skills (Chonko and Jones, 2005) and help the salesperson evaluate } \\
\text { customer needs and respond swiftly to satisfy them }\end{array}$ \\
\hline $\begin{array}{l}\text { Paul, Jena, \& Sahoo, } \\
2020, \text { p. } 136\end{array}$ & 4 & An organization must nurture agility among its employees in order to succeed \\
\hline
\end{tabular}




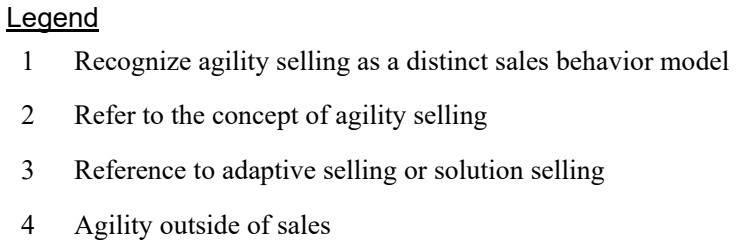

Unfortunately, none of the articles has agility selling as the core focus of their research. Consequently, they contain little empirical research and contributions on this specific topic. Other documents were found and consulted during our research, notably Gias (2016) who operationalized an agility scale, but alas, they do not appear in Table 1 as they were not published in peer-reviewed journals. Agility selling has experienced, as of late, an uptick of interest with 11 of the 24 citations occurring in the last four years. We note that no research has demonstrated that agility selling, although conceptually logical, empirically exists nor explains how a salesforce can act with responsiveness, a central theme in agility selling. Our article is positioned to address this gap.

\section{Methodology}

A descriptive line of inquiry was deemed appropriate due to the limited empirical work on agility selling. Descriptive case studies help to achieve an in-depth understanding of a theory (Yin, 2014) and are suitable "in studying topics that have not attracted significant previous sales research attention" (Javalgi et al., 2011, p.159). They are appropriate when trying to provide a deep understanding of actors and their interactions (Woodside and Wilson, 2003). We followed the best practice recommendations proposed by Piekkari et al. (2010). We also incorporated the recommended methodological innovations when conducting case study in industrial marketing 
research such as relating theory and practice, using theoretical sampling for cases, including an Emic /Etic perspective, approaching cases studies through critical events, and validating case studies with follow-up participant discussions.

Multiple case studies help better capture a variety of contexts (Karjaluoto, Mustonen and Ulkuniemi, 2015) and have often been used in industrial marketing. For example, Carlborg \& Kindström (2014) studied three firms to compare how they deployed different service types across their customer base. Lashgari et al. (2018) chose four companies for their multiple case study approach in analyzing social media adoption by B2B firms.

As recommended by Visconti, (2010) we used an ethnographic case study methodology to examine exchanges between customer and supplier in a B2B context. This approach combines ethnographic methods, such as the membership of one of the researchers in the organization under study, with case study research, which includes tools such as theoretical sampling (Eisenhardt and Graebner, 2007). It promotes co-authorship of case studies during researcher/practitioners' reflexive interactions which is in accordance with recommendations when theorizing with stakeholders (Brodie et al., 2017).

\subsection{Data collection}

Data collection occurred in two steps. The first step was an organizational autoethnography (Boyle and Parry, 2007; Doloriert and Sambrook, 2012) where a researcher recollected eight short case studies of critical events and turbulence from his personal experience as vice-president of sales through a process in which he was simultaneously an actor in the case study as well as the researcher (Lapadat, 2017). B2B marketing research has been slow in using 
this methodology despite encouragements in the Journal of Business \& Industrial Marketing to do so (Lowe, Rod and Hwang, 2016). In fact, only one other study published in a major B2B academic journal (Kelly et al., 2020) has used this methodology despite its widespread use in social research (Lapadat, 2017). We followed Alvesson's (2003) recommendation to collaborate with a co-researcher from outside of the case study to help create distance with the autoethnographer. After the stories were written, the outside researcher initiated an iterative process of "counterarguments" and "intentional skepticism" (Schouten \& McAlexander, 1995, p.47).

To capture the richness of details in the case studies, both researchers looked for the meaning behind the stories, using their own sensitivity, biases, and knowledge (Corbin and Strauss, 2015). When the researchers interpreted the initial drafts of the stories, they relied on the hermeneutic circle or spiral (Gummesson, 2003), as they moved back and forth between understanding and pre-understanding. The stories were rewritten, discussed, and rewritten again. To improve reliability, retrospective accounts should use multiple informants who view the phenomenon from different perspectives in order to reduce the risk of bias (Eisenhardt and Graebner, 2007), which is the reason the next step was undertaken.

The second step of data collection consisted of complementing the case studies through semi-structured in-depth audio-recorded interviews that lasted between 30 and 50 minutes and collected over a six-month period. During this step the autoethnography became collaborative (Chang, Ngunjiri and Hernandez, 2016) with the help of the informants, Nataly, Tony, and Frank, who were selected because of their key role in each case study. They had more than twenty years experience in the industry under study and had been managing annual sales of 
USD $\$ 10$ to $\$ 20$ million at the time the events occurred. Their interactions with each of the customers mentioned in the case studies lasted from six to fourteen years. In order to establish a climate of trust, the interviews started with general questions on the type of relationship the salesperson had with customers. The researcher then invited the informants to share their version of the case studies. The informants also rated each turbulence in terms of valence for the supplier and for the customer., Construct validity was strengthened through data triangulation (Yin, 2014), here the researcher and the informant. Informants further contributed to the validity of the final version of the case studies by confirming the researcher's understanding of their perspective, a process labelled "member check" (Lincoln and Guba, 1985). This line of questioning allowed them to co-create knowledge by sharing their views of the case studies (Ellis, Adams and Bochner, 2010; Takhar-Lail and Chitakunye, 2015) and to describe their roles when dealing with the turbulence. The data collection ceased when additional case studies provided marginal knowledge and therefore theoretical saturation was achieved (Eisenhardt, 1989).

Table 2 presents the eight descriptive case studies that occurred during a ten-year period, during which time the focal organization, PackagingCo, operated twenty folding carton manufacturing plants and made more than $\$ 1$ billion (USD) in sales annually. Our number of participants follows the guidelines set by previous research in industrial marketing on critical events (Tidström and Hagberg-Andersson, 2012). 
Table 2: Summary of eight descriptive case studies

\begin{tabular}{|c|c|c|c|}
\hline $\begin{array}{l}\text { Case } \\
\text { study }\end{array}$ & Title & Informants & Summary \\
\hline 1 & Going South & Tony and Researcher & $\begin{array}{l}\text { A customer's plant moves to Mexico (critical event) and } \\
\text { transportation costs become prohibitive (turbulence). }\end{array}$ \\
\hline 2 & Give and Take & Nataly and Researcher & $\begin{array}{c}\text { PackagingCo negotiates a price increase (turbulence) after costs } \\
\text { surge (critical event). }\end{array}$ \\
\hline 3 & New Product Launch & Nataly and Researcher & $\begin{array}{l}\text { A new product launch (critical event) creates a disruptive process } \\
\text { (turbulence) in PackagingCo's production. }\end{array}$ \\
\hline 4 & The Right Tool & Tony and Researcher & $\begin{array}{l}\text { New regulations (critical event) create a sales opportunity } \\
\text { (turbulence) for PackagingCo. }\end{array}$ \\
\hline 5 & Seize the Moment & Frank and Researcher & $\begin{array}{l}\text { A sudden exchange rate fluctuation (critical event) drives a new } \\
\text { product line (turbulence) at PackagingCo. }\end{array}$ \\
\hline 6 & The Missing Link & Tony & $\begin{array}{l}\text { Decisions by transportation suppliers to focus on seasonal } \\
\text { deliveries (critical event) impede deliveries (turbulence) to } \\
\text { PackagingCo's customer. }\end{array}$ \\
\hline 7 & A Bitter Pill to Swallow & Researcher & $\begin{array}{l}\text { PackagingCo's plant closure (critical event) threatens the } \\
\text { relationship (turbulence) with a pharmaceutical customer. }\end{array}$ \\
\hline 8 & Proactive Cost Savings & Nataly and Researcher & $\begin{array}{c}\text { Electronic reverse auctions (critical incident) threaten } \\
\text { PackagingCo's existing relationship (turbulence) with a customer. }\end{array}$ \\
\hline
\end{tabular}

\subsection{Data interpretation}

Data interpretation, the process by which the researchers try to understand the meaning of the data (Patton, 2002), consisted of four steps. In the first step, the concepts of critical events, turbulence, and the responsive roles of the salesperson emerged (Töytäri et al., 2011) from the autoethnographer's initial recollection. In the second step, the data was then compared with the literature to understand the phenomenon. In the third step, the interpretation continued when the autoethnographer and the informant co-created the case studies (Shankar, Elliott and Goulding, 2001). In the fourth and final step, the researchers compared and contrasted all eight case studies and searched for patterns and similarities in the interviews (Polkinghorne, 2007). 


\section{Results}

The following eight case studies are related to critical events and the subsequent turbulence they generated between PackagingCo and its customers. They demonstrate the responsiveness of PackagingCo's salesforce during turbulence.

\section{Case study 1: Going South}

A beauty products organization decided to relocate its manufacturing facility to Mexico where manufacturing costs were lower. PackagingCo, which supplied the highly designed packaging for these products, was consequently going to lose a major customer as the cost of transporting the cartons from Canada to the future Mexican plant was going to be cost prohibitive. Although the customer was generally satisfied, the relationship was going to end. This created a sense of urgency for the salesperson to do anything possible to keep this major customer.

The sales team looked into ways of maintaining the relationship with the customer either by buying an existing carton manufacturing Mexican plant, creating a joint venture with a local competitor, opening a new manufacturing facility next to their customer's new Mexican facility, and expanding some of their nearby subsidiaries to support production of the required products. When asked why it was the sales team's role to investigate moving its production facility to another country, Tony answered: 
"That's a good question. We took care of the problem because we were responsible to maintain sales level with the customer. The sales team took care of possibly relocating production much more than anyone else. Why did the sales team take the lead on this problem? Because we wanted to keep the customer. The production staff wouldn't have worked on the problem because the production plant was losing the production in any case."

At the end, PackagingCo did not find a satisfying solution and lost the volume that was moved to Mexico. However, the sales team uncovered a new Mexican customer during their effort, which compensated part of the lost business.

Case study 2: Give and Take

Customers of the folding carton division generally felt that PackagingCo, as a vertically integrated organization, should not pass on the price increases set by the division that supplied paperboard. They would argue that the price increase was an internal issue. Even though the contracts were written in a manner to entitle PackagingCo to increase its price when the cost of raw material would increase, such an event often resulted in a delicate situation where the sales team had to manage the customer's dissatisfaction. If negotiation dragged on, PackagingCo would not benefit in the meantime from the price increase and therefore it was important to obtain an agreement rapidly. The salesperson, Nataly, when facing resistance from customers, used a combination of negotiation abilities mixed with creativity:

"I would get creative in terms of solutions for a price increase. I might go back and say: 'Can we get a two-year contract?' or 'Could you give us more business? If you increase our business here then maybe we could close our eyes over here on this raw material increase. [...] If I can have any increase here, I will give you a rebate so that it would offset a price increase." "

In such instances, the sales team had to convince its own folding carton plant that the deal would be profitable for both parties. The sales team would transform a difficult situation by 
alleviating the price increase to its customer and generating additional business for its organization.

Case study 3: New Product Launch

New product launches represented a delicate period for customers and PackagingCo. Time was of the essence and things could quickly go wrong. This stressful, costly, and complex operation required the coordination of numerous resources both internally and externally. Asked about a specific launch opportunity, Nataly explained that she had positioned PackagingCo favorably by having rallied multiple internal resources to design a solution collaboratively with the client before the contract was awarded:

"You are trying to find that unique out-of-the-box solution that is going to differentiate you from your competitors."

Once the project had been awarded to PackagingCo, Nataly would run a very tight ship over the implementation. Because of her boundary-spanning role, she would provide accurate information to the launch teams to ensure a smooth process. She would also monitor the entire process very closely to ensure that PackagingCo delivered on time "having to babysit every step of the project to make sure that nothing gets missed." Nataly's careful planning and tight control allowed the new product launch to be a success for both companies.

\section{Case study 4: The Right Tool}

Tony, a salesperson, considered a tobacco manufacturer as one of his best customers. Even though the manufacturer was in a declining market and PackagingCo was only a supplier of a secondary product line, price negotiations always went smoothly and the quality of the relationship was excellent. In return, he would ensure that product quality was impeccable: 
"If we ever had quality problems, we would turn around and redo the products".

Unfortunately for the customer, ever tightening regulations on tobacco packaging continuously increased the size and number of health warnings on their packaging and consequently decreased the legally allocated space for branding. With each modification, the tobacco manufacturer had to invest in very costly re-tooling to modify its packaging. Fortunately for PackagingCo, its printing process was better adapted for smaller batches, frequent modifications, and allowed for crisper text on the ever declining permissible branding space. Because the sales team had sensed the changing legal environment and had positioned PackagingCo as a suitable alternative to the dominant suppliers of the tobacco industry, PackagingCo was at an advantage when major legal changes were officially announced. Tony is now working with the production team to position PackagingCo to take the market when the next regulations will come into play:

"We want to be leaders in the tobacco market and we're working really hard at it. We're already positioned in the short term with what we're capable of doing. We're working on the medium term regarding the upcoming regulations, but we're also working on the very long term with scenarios that might occur."

Case study 5: Seize the Moment

A very large American manufacturer of beauty products was using a very complicated form of packaging that required a specialized gluer only available in Germany. Currency fluctuations were reducing the manufacturer's buying power in Europe while simultaneously increasing it in Canada. Exchange rates can vary without warning so the sales team had to execute the transition quickly to avoid another currency change in favor of the German supplier. 
The sales team seized this opportunity with a threefold approach. First, before the critical event, it had maintained excellent relationships with the customer despite being confined to the role of a lower-tier supplier. Second, it actively pushed for PackagingCo to invest in a new specialized gluer so that it could develop the technical capabilities to support the manufacturer's requirements. The salesperson on the account, Frank, recognized the impact of the gluer investment:

"Our company made the investment in advance to pick up this customer. They would not have awarded us the contract prior to us having the capability. Investing in the glue line had a very big impact."

Finally, during the transition, the sales team led a group of employees who worked closely with the customer's engineers and graphic artists to match their carton design to the new equipment's specifications and to maintain the level of quality to which the customer had been accustomed. The consequences for PackagingCo were major.

"Although we were already doing business in the United States, we weren't that well known. I think our name became one of the top 5 or 6 carton companies after we started getting that type of business or volume. It put us on the map. We really became a significant player".

\section{Case Study 6: The Missing Link}

The harvest season increases demand on trucking organizations that have an opportunity to transport fresh produce at a higher price. With limited buying power over the trucking organizations, PackagingCo would have cartons stalled in its warehouse every year during this period. Tony recalls a particular incident where the delayed delivery was generating out-of-stock all the way to the retail level for his customer: 
"On our side, everything was going well. Then, when we would call a truck for a pick-up, they would confirm but simply wouldn't show up. The customer was upset because the delays also created packaging material stock-outs and they would have to reschedule their production."

Nonetheless, in response to this challenge, the sales team took it upon themselves to support its logistical team in finding a solution for the customer. Due to sales team's efforts, the shipment was delivered more quickly.

\section{Case Study 7: A Bitter Pill to Swallow}

Pharmaceutical manufacturers are very particular about their suppliers' quality procedures. As such, packaging plants must demonstrate a pristine manufacturing environment. Any change of supplier or manufacturing location has to be approved by the pharmaceutical manufacturer's quality department, which necessitates a strict process and significant effort from multiple stakeholders. When PackagingCo decided to close a less profitable plant, it was the sales team's role to convince the pharmaceutical manufacturer that the move of their packaging production from an approved plant to a non-approved plant would have minimal impact. They organized a plant visit for the pharmaceutical manufacturer and arranged meetings with the plant's key personnel. If the plant transition did not happen quickly and smoothly, there was the risk that the customer could invite a competitor to bid on the product line. The sales team helped to create a formal transition plan to support the complex process of transitioning operations from one manufacturing plant to another. As a result of the sale's team involvement, the pharmaceutical manufacturer kept PackagingCo as a supplier and, after a few months of good-quality production, invited it to bid on more product lines.

Case Study 8: Proactive Cost Savings 
Technological advancements have generalized electronic bidding mechanisms. When manufacturers employ these tools, it often means that their suppliers will have to lower their margins or, worse yet, lose business. Nataly would pre-emptively try to avoid the bidding process. With new projects, she would come up with creative ways to differentiate her solution. With existing products, she would propose cost saving opportunities that would cause PackagingCo to reduce its margins, but still keep the customer. She had to move swiftly or else the bidding process would move forward.

"When you hear that a new project is coming down the pipeline, you have to be very proactive. You try to find that unique out-of-the-box solution that is going to differentiate you from your competitors[...] You have to be proactive and try to avoid the bid altogether. You do that by trying to come back to the customer and say 'we looked at your business.' You need to find out what their objectives are very quickly and try to meet their objectives right away and talk them into not spending money on transitions."

\section{Discussion}

All of the case studies illustrate how salespeople are responsive when a critical event occurs and the ensuing turbulence affects the dyad. They either exploit opportunities or minimize threats. We contend that salespeople consider the effect on the supplier as much as the effect on the customer and we adapted Chonko and Jones' model accordingly.

\subsection{Four categories of responsiveness}

Turbulence can be either positive or negative for each of the two parties in a dyadic relationship (the customer and the supplier). For example, turbulence would be positive for the supplier when it increases profits and negative otherwise. Since the role of the salesperson is to ensure satisfaction for the customer and for the supplier, the salesperson should aim to reduce the 
negative influence of turbulence or to enhance its positive influence. By combining these two axes, a matrix can serve to illustrate four different situations that affect the dyad. The case studies illustrate how the salesforce took four responsive roles to respond to turbulence.

Figure 1: The four responsive roles of the salesforce in agility selling

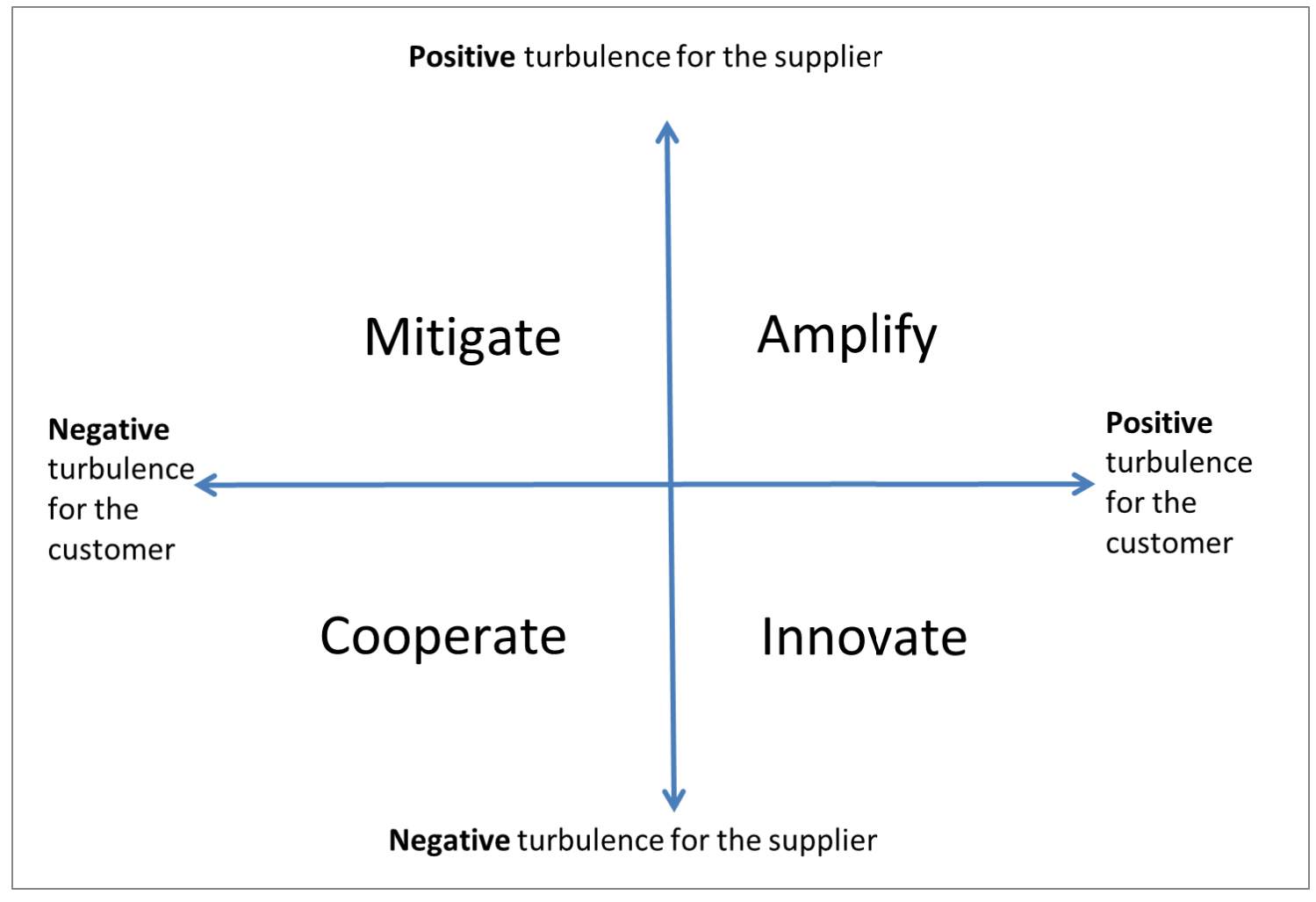

Amplify

As illustrated in Figure 1, when turbulence has a positive effect on both the customer and the supplier, the salesperson's dual role is to amplify the impact of the turbulence for both of them. This role was observed in Case Study 3: New Product Launch when Nataly carefully monitored all the manufacturing steps of the new product packaging components. It was also observed in Case Study 5: Seize the Moment when Frank led an ad hoc team of customer's and 
PackagingCo's employees to smooth out the transition of a complicated form of packaging from a European supplier to PackagingCo.

\section{Innovate}

When turbulence has a positive effect on the customer but a negative one on the supplier, the salesperson must find ways to sustain the supplier's satisfaction and innovate to find new opportunities. In Case Study 1: Going South, when the sales team at PackagingCo learned that it would be losing millions of dollars of revenue because of the customer's decision to offshore its production, it needed to innovate quickly. The sales team's decision to meet its customer's needs in a new territory created new unexpected opportunities. In Case Study 8: Proactive Cost Savings, the sales team innovated by generating cost saving initiatives to prevent the customer from examining other supplier offerings. Agility selling helped in anticipating problems and minimizing their negative impact.

\section{Cooperate}

Turbulence can be negative for both the supplier and the customer. In such an instance, the salesperson should encourage both parties to cooperate to minimize its negative impact. Case Study 4: The Right Tool exemplifies this responsive role. The new tobacco regulation was negative for both organizations because of the declining volume, but by cooperating the salesperson turned a negative impact into a positive one by increasing sales for PackagingCo while minimizing costs for the customer. In Case Study 6: The Missing Link, the salesperson's cooperative approach with the customer enabled the company to get cartons delivered in order to resolve a delicate situation for the customer and minimize the negative impact of the turbulence. 


\section{Mitigate}

Finally, turbulence can be negative for the customer but positive for the supplier. In this case, the salesperson will attempt to bridge the gap between the effects the turbulence has on both parties. This could be accomplished either by downplaying the supplier's benefit or by reducing the negative effect of the turbulence on the customer. This would be the mitigating category of responsiveness. In Case Study 2: Give and Take, the supplier attempted to obtain something in exchange for reducing its own benefit. In Case Study 7: A Bitter Pill to Swallow, the sales team reduced the negative effect of the turbulence on the customer by easing the move of its operations from one plant to another. In this category negotiating skills, "finding a compromise between the interests of the supplier and the interests of the customer." (Homburg et al., 2011, p.57), might be more crucial than in any other roles.

\subsection{Theoretical implications}

There is abundant research into, and using, critical events. Likewise, there is a growing trend of B2B research into turbulence (e.g., Blocker et al., 2012; Chonko et al., 2002;

Edvardsson et al., 2014; Prince et al., 2016). Despite that both concepts offer interesting and deep insights into the theory of relationship dynamics set forth by Palmatier et al. (2013), they are generally treated as independent concepts with very little linkage between the two. A notable exception (Edvardsson et al., 2014) posits that a critical incident will create a "negative critical wave" of turbulence, a disturbance in a relationship that spreads through the surrounding business network. This concept is very similar to our belief that critical events are the cause of the turbulence that the salesforce must eventually deal with before or once it hits the dyad it is 
overseeing. Our study enriches this framework by demonstrating that turbulence can have a positive effect through the responsive roles of the salesforce. It also builds upon research that had identified the presence of positive critical incidents (Odekerken-Schröder et al., 2000) in consumer marketing and of Gryskiewicz (2000) who independently mentioned the existence of positive turbulence.

Since agility selling was introduced 15 years ago, the marketing literature positioned it as a sales behavior, which is indeed correct, but by doing so did not emphasize its role in the overall concept of business agility or organizational agility. Agility selling fits nicely into the domain of agile marketing, which is currently gaining increased attention (Zhou, Mavondo and Saunders, 2019) as an organizational capability required to face critical events and turbulence. Other areas of research could also benefit from incorporating agility selling. As identified in our literature review, several articles on workforce agility already reference agility selling, but more research is needed on agile selling's place within the overall agile organization.

By illustrating agility selling responsiveness, the study empirically demonstrates the existence of agility selling and highlights the difference that exists with other sales practices developed over the course of the last thirty years. We agree with Terho et al. (2012) that agility selling is a distinct sales behavior in comparison to adaptive selling, relationship selling, consultative selling, customer-oriented selling, partnering oriented selling, and value-based selling. Having demonstrated that agility selling is a unique sales behavior, the article then contributes to the agility selling model in the following ways. It contributes to knowledge of how the salesforce can perform agility selling by proposing specific responsive roles. It simplifies the agility selling model for the sake of parsimony. Instead of seventeen general agile strategies suggested in the seminal article, four encompassing roles are presented based on the 
negative/positive impact of the turbulence on the customer/supplier. It proposes to expand the agility selling model by incorporating critical events as antecedents of turbulence (Edvardsson $e t$ al., 2014). By observing the cause of the turbulence before turbulence appears, the agile salesperson is in a position to proactively identify future customer needs, an agile selling trait that has the added benefit of contributing to proactive market orientation (Wang et al., 2017).

The article also contributes by expanding agility selling abilities. Chonko and Jones (2005) identified two core abilities required by an agile salesforce: responding to change and exploiting it. However, in light of our research, we propose a third ability: "forecasting turbulence from critical events" to deal with predictable and anticipated change. The original agility selling concept already included "sensing" in a minor role given that agile salespeople are "constantly sensing and responding to the changing business environment" (Chonko \& Jones, 2005, p.379). Forecasting, however, goes beyond sensing and attempts to predict turbulence before it forms, after the critical event has occurred. We contend that salespeople play the role of first responders to business turbulence. As boundary spanners, they build and manage relationships, which places them at the forefront of the external environment where they become the de facto sense organs of the organization by providing sensory input and responding to external stimuli. As such, we propose to bring the notion of sensing forward into a new trio of core agile selling abilities while simultaneously replacing it with a term that aligns itself better with turbulence terminology and that communicates that agile selling should include an early warning system with contingency plans: forecasting - responding - exploiting.

\subsection{Managerial Implications}


How can a salesforce become more agile during times of turbulence? Practical advice that is based on our data and current level of research will be given to the salesperson who wishes to become more agile as well as to the manager who wishes to benefit from the advantages of an agile salesforce. Essentially, we suggest a three-prong approach that aims at improving each core capability of the agile salesforce: forecasting turbulence from critical events, responding to changes quickly, and adequately exploiting these changes as opportunities.

\subsubsection{Forecasting turbulence from critical events}

Being able to forecast turbulence means predicting that a critical event will have an impact on the dyad for which the salesperson is responsible. This naturally implies two activities. First, the salesperson must discover that a critical event has in fact taken place or is about to. Secondly, the salesperson needs to be capable of interpreting the critical event to understand that it will become turbulence that needs to be dealt with.

Finding out about a critical event is all about acquiring more of the right data earlier. The agile salesperson is always on the lookout for relevant critical events to avoid being blindsided. This can be achieved by asking questions about what is happening and what is coming up inside the organization, not just about what is related to the next sale. To improve the quantity of information collected, the agile salesperson collects more information through a network that has a wider and deeper net at more customer locations and which reaches at different levels within several functional areas. To encourage information sharing, the agile salesperson is seen as a trusted advisor and has built trust. 
Sales managers have an important role to play in forecasting turbulence. First, they can implement monitoring software to extract information automatically from digital platforms like social media, forums, and websites (Bolat, Kooli and Wright, 2016) that will provide advance warning of upcoming critical events and turbulence. Another technological tool that managers can oversee is a customer relationship management (CRM). To be useful, special care must be taken to make sure that information is correctly entered in the software and that it is disseminated through the internal network. Sales managers can also create opportunities for their sales team to keep up-to-date with industry events by valuing these activities with their team and other internal stakeholders. To improve its reaction time, managers should push their sales team to look further to see earlier. For example, managers can encourage their sales team to gather information upstream in the business network in order to be keenly aware of the changes affecting their customers' customers. While collecting information is mostly the salesperson's responsibility, interpreting it will mostly be the responsibility of the sales managers who have access to the overall picture. It can be conducted within small ad-hoc committees consisting of salespeople servicing accounts in the same industry or in the same region and internal employees such as technical advisers or customer service representatives.

When analyzing and interpreting the effect of turbulence, managers should keep an eye on potential supplier and competitor responses.

\subsubsection{Responding to changes quickly and adequately}

The trademark of an agile salesforce is one that responds quickly and adequately. To increase response time, a salesperson must first develop the correct attitude towards time. An agile salesperson understands that speed is of the essence because customers and environmental 
conditions can change rapidly. Specifically, it avoids being a bottleneck and in delaying to address turbulence. This implies being available when the customer needs the salesperson. In some circumstances that means being available 24/7. Being agile also means using what little time is available more efficiently by properly establishing priorities and using time management tools in order to accomplish more important activities quickly. An agile salesperson also knows how to delegate while staying accountable and makes sure that the task keeps moving down the organizational pipeline smoothly and swiftly. An agile salesperson also responds with efficiency. This is accomplished by staying focused on a solution that will meet the customer's and the supplier's objectives. To ensure buy-in and avoid working in the wrong direction the customer can sometimes become a co-creator of the solution. The solution will also make sense financially and technically the first time around because the different supplier's internal departments are involved.

Managers have an important role in helping their sales team respond more quickly. In addition to nurturing a culture of speed within their team, they can develop support mechanisms to encourage that sale solutions are developed without a hitch. Specifically, managers can streamline the internal processes, remove internal obstacles for its sales team by creating a customer-oriented culture, and make sure that the necessary resources, technical assistance, and administrative support are available. If agile salespeople should consider being available 24/7 for customers, then managers should also be prepared to show the same availability for their sales team in order to support them during urgent requests. Managers also have a role in ensuring that responses adequately meet customer needs. They must make sure that the firm properly supports the salesforce in their agile selling approach. Links between the sales team and the rest of the 
organization must be strong, corporate buy-in into supporting selling with agility necessary, and the team should have access to the best and most competent resources.

\subsubsection{Exploiting changes as opportunities}

An agile salesperson exhibits a mindset where it is always looking to exploit turbulence no matter if it is negative or positive. It is easy to exploit positive turbulence. Exploiting negative turbulence requires experience and is where an agile salesperson demonstrates its value. When turbulence is negative, salespeople ask themselves: "How can I turn this situation around?" An agile salesperson will rally resources when required. Creative ideas can be generated during brainstorming sessions or through group discussions with internal trusted advisors such as members of the technical team and other colleagues. Being flexible and creative are two essential qualities. A starting point might be to use the four responsive sales roles to envision how to maximize the benefit for the dyad, amplify the benefits of the positive turbulence to both parties, innovate by anticipating problems and minimizing the negative impact of a turbulence on the supplier, cooperate with the customer to minimize the negative impact of the turbulence on both parties, or mitigate the negative impact of the turbulence on the customer when the turbulence is positive for the supplier. If the opportunity is not at one end of the dyad then maybe it is at the other end, or perhaps the opportunity is a preventive one.

Sales managers can certainly assist in exploiting change. From a financial resource perspective, they can secure additional budget to perform R\&D that will help their sales team identify solutions to anticipated problems. From a human resource perspective, they can procure sales training on soft skills such as adaptation, creativity, and readiness to change. Some researchers believe that experience in dealing with turbulence can be developed through 
exposing the salesforce to turbulence (Bolander, Dugan and Jones, 2017). Using this approach, a less experienced salesperson can be "forged by fire" in a somewhat controlled environment where less turbulence is present or by being accompanied by a more experienced sales colleague.

Managers can also guide a less agile sales person by discussing how to respond to a given turbulence and identifying which resources are available to deal with it. Sessions where colleagues share their experience with turbulence can also be organized. Training is always useful, but to have an agile salesforce, it is easier to start with a salesperson who already has the agile selling mentality and abilities. Since responding requires the flexibility to leave the beaten path to craft new value propositions (Chonko and Jones, 2011), managers should look for creativity during the hiring process.

\section{Conclusion}

Using an organizational autoethnography and then in-depth interviews to collect the data collaboratively, this paper presented eight descriptive case studies that describe four responsive roles that a salesforce takes when selling with agility. These roles, namely to amplify, innovate, cooperate, and mitigate, are used as a response to business turbulence that originated from a critical event in the business network and aim to maximize its positive effect or minimize its negative impact. The paper contributes to an increasingly relevant business context where agility is required and where notably very little empirical research has yet been performed. It is the first study to demonstrate empirically the existence of agility selling as a distinctive sales behavior. The paper has also provided a conceptual and managerial tool to help the salesperson visualize how to respond to a turbulence when using an agility selling approach. 


\section{Limitations and Future Research}

The current study includes some limitations, which also serve as opportunities for future research. First, the interviews were obtained from members of a single North American sales team in the packaging industry. Data from other organizations, industries, or countries would make the agility selling framework more robust. Second, the case studies were narrated from the supplier's side and from the point of view of the sales team. Customers, or other members of the sales organization, could have a different perspective on the role played by the salesperson. A study into this perspective could provide some interesting insights into how customers perceive the effect of the salesforce's responsiveness on their organization. Triangulating responses from both sides of the buyer-seller dyad and the extended strategic network (Möller and Halinen, 1999) would also advance this research topic, The ability of our informants to recollect specific details could be the third limitation of our study given that the events discussed date back from several years. One of the challenges with retrospective accounts is that informants may have memory lapses or want to paint a nicer picture of their own or their organization's actions (Miller, Cardinal and Glick, 1997). To address this limitation, which is inherent to all forms of in-depth interviews that recollect past events, we followed Miller et al.'s recommendations of using multiple informants, focusing on facts rather than opinions, and motivating informants to provide accurate information.

Future research could examine whether the salesperson's role varies depending on which organization is first hit by the turbulence. As for when both organizations are hit simultaneously and a salesperson needs to develop cooperation, it could be interesting to examine whether opportunism is present (Grandinetti, 2017), and if the power relationship between customer and 
supplier influences the choice of strategies (Lacoste and Blois, 2015). Another interesting venue for research would be to explore the sales manager's or top management's role or the involvement of other functional areas in defining the strategies in times of turbulence. Finally, agility selling could be considered along with other strategies for managing turbulence such as entrepreneurial motivation (Rajabi, Brashear-Alejandro and Chelariu, 2018) and salesperson's improvisation (Banin et al., 2016). 


\section{References}

Alavi, S., Abd. Wahab, D., Muhamad, N., \& Arbab Shirani, B. (2014). 'Organic Structure andOrganisational Learning as the Main Antecedents of Workforce Agility'. International Journal of Production Research, 52(21), 6273-6295.

https://doi.org/10.1080/00207543.2014.919420

Alvesson, M. (2003) 'Beyond Neopositivists, Romantics, and Localists: A Reflexive Approach to Interviews in Organizational Research', Academy of Management Review, 28(1), pp. 13-33. doi: 10.5465/AMR.2003.8925191.

Appelbaum, S. H. et al. (1997) 'The Survivor Syndrome: Aftermath of Downsizing', Career Development International, 2(6), pp. 278-286. doi: 10.1108/13620439710178639.

Bachrach, D. G., Mullins, R. R. and Rapp, A. A. (2017) 'Intangible Sales Team Resources: Investing in Team Social Capital and Transactive Memory for Market-driven Behaviors, Norms and Performance', Industrial Marketing Management. Elsevier Inc., 62, pp. 88-99. doi: 10.1016/j.indmarman.2016.08.001.

Banin, A. Y. et al. (2016) 'Salesperson Improvisation: Antecedents, Performance Outcomes, and Boundary Conditions', Industrial Marketing Management. Elsevier B.V., 59(November), pp. 120-130. doi: 10.1016/j.indmarman.2016.02.007.

Blocker, C. P. et al. (2012) 'The Role of the Sales Force in Value Creation and Appropriation: New Directions for Research', Journal of Personal Selling and Sales Management, 32(winter), pp. 15-28. doi: 10.2753/PSS0885-3134320103.

Boeck, H., Bendavid, Y. and Lefebvre, E. (2009) 'Evolving B2B E-Commerce Adaptation for SME Suppliers', Journal of Business \& Industrial Marketing, 24(8), pp. 561-574. doi: $10.1108 / 08858620910999439$.

Bolander, W., Dugan, R. and Jones, E. (2017) 'Time, Change, and Longitudinally Emergent Conditions: Understanding and Applying Longitudinal Growth Modeling in Sales Research', Journal of Personal Selling and Sales Management, 37(2), pp. 153-169. doi: 10.1080/08853134.2017.1314187.

Bolat, E., Kooli, K. and Wright, L. T. (2016) 'Businesses and Mobile Social Media Capability', Journal of Business \& Industrial Marketing, 31(8), pp. 971-981. doi: 10.1108/JBIM-10-2016270.

Bonney, L., Plouffe, C. R. and Wolter, J. (2014) "“I think I can...I think I can": The Impact of Perceived Selling Efficacy and Deal Disclosure on Salesperson Escalation of Commitment', Industrial Marketing Management. Elsevier Inc., 43(5), pp. 826-839. doi:

10.1016/j.indmarman.2014.04.010.

Bourguignon, B., Boeck, H. and Clarke, T. B. (2020) 'An Exploration of Supplier Decision- 
Making under Threat', Journal of Business-to-Business Marketing.

Boyle, M. and Parry, K. (2007) 'Telling the Whole Story: The Case for Organizational Autoethnography', Culture and Organization, 13(3), pp. 185-190. doi:

10.1080/14759550701486480.

Brodie, R. J. et al. (2017) 'Theorizing with Managers to Bridge the Theory-praxis Gap:

Foundations for a Research Tradition', European Journal of Marketing, 51(7/8), pp. 1173-1177. doi: 10.1108/EJM-03-2017-0175.

Carlborg, P. and Kindström, D. (2014) 'Service Process Modularization and Modular Strategies', Journal of Business and Industrial Marketing, 29(4), pp. 313-323. doi: 10.1108/JBIM-08-20130170 .

Chang, H., Ngunjiri, F. W. and Hernandez, K.-A. C. (2016) 'What is Collaborative Autoethnography?', in Collaborative Ethnography. Walnut Creek: Left Coast Press, p. 200.

Chonko, L. B. et al. (2002) 'The Role of Environmental Turbulence, Readiness for Change, and Salesperson Learning in the Success of Sales Force Change', Journal of Personal Selling \& Sales Management, XXII(4), pp. 227-245.

Chonko, L. B. and Jones, E. (2005) 'The Need for Speed: Agility Selling', Journal of Personal Selling \& Sales Management, 15(4), pp. 371-382. doi: 10.1080/08853134.2005.10749071.

Chonko, L. B. and Jones, E. (2011) Sales Force Agility, Strategic Thinking, and Value Propositions, The Oxford Handbook of Strategic Sales and Sales Management. Edited by D. W. Cravens, K. Le Meunier-FitzHugh, and N. F. Piercy. Oxford University Press. doi: 10.1093/oxfordhb/9780199569458.003.0019.

Christopher, M. (2000) 'The Agile Supply Chain: Competing in Volatile Markets', Industrial Marketing Management, 29, pp. 37-44. doi: 10.1080/13241583.2008.11465337.

Chu, P., Chang, K. and Huang, H. (2012) 'How to Increase Supplier Flexibility through Social Mechanisms and Influence Strategies?', Journal of Business \& Industrial Marketing, 27(2), pp. 115-131. doi: 10.1108/08858621211196985.

Corbin, J. and Strauss, A. (2015) Basics of Qualitative Research Techniques and Procedures for Developping Grounded Theory. 4th edn. Los Angeles: Sage.

Doloriert, C. and Sambrook, S. (2012) 'Organisational Autoethnography', Journal of Organizational Ethnography, 1(1), pp. 83-95. doi: 10.1108/20466741211220688.

Edvardsson, B. et al. (2014) 'Negative Critical Waves in Business Relationships: An Extension of the Critical Incident Perspective', Journal of Business \& Industrial Marketing, 29(4), pp. 284 294. doi: 10.1108/JBIM-08-2013-0159.

Edvardsson, B. and Strandvik, T. (2000) 'Is a Critical Incident Critical for a Customer 
Relationship?', Managing Service Quality, 10(2), pp. 82-91.

Eisenhardt, K. M. (1989) 'Building Theories from Case Study Research.', Academy of Management Review, 14, pp. 532-550. doi: 10.5465/AMR.1989.4308385.

Eisenhardt, K. M. and Graebner, M. E. (2007) 'Theory Building from Cases: Opportunities and Challenges', The academy of management journal, 50(1), pp. 25-32. doi: Article.

Ellis, C., Adams, T. E. and Bochner, A. P. (2010) 'Autoethnography: An Overview', Forum Qualitative Sozialforschung / Forum: Qualitative Social Research, 12(1).

Elo, M. N. K., Halinen, A. and Törnroos, J.-Å. (2010) 'Process Research in Business Networks an Event-Based Method for Qualitative Analysis', in 26th IMP Conference in Budapest, pp. 118.

Geersbro, J. and Ritter, T. (2010) 'External Performance Barriers in Business Networks: Uncertainty, Ambiguity, and Conflict', Journal of Business and Industrial Marketing, 25(3), pp. 196-201. doi: 10.1108/08858621011027786.

Gias, S. (2016) An Essay on Salesforce Agility: Is the Concept Worthy of Study? University of Texas Arlington. Available at: https://rc.library.uta.edu/uta-ir/handle/10106/26145.

Grandinetti, R. (2017) 'Exploring the Dark Side of Cooperative Buyer-Seller Relationships', Journal of Business \& Industrial Marketing, 32(2), pp. 326-336. doi: 10.1108/JBIM-04-20160066 .

Gryskiewicz, S. S. (2000) 'Positive Turbulence is Key to Organizational Renewal: Using Creativity to Manage Change and Sustain Healthy Organizations', Social Marketing Quarterly, 6(3), pp. 44-49. doi: 10.1080/15245004.2000.9961117.

Gummesson, E. (2003) 'All Research is Interpretive!', Journal of Business \& Industrial Marketing, 18(6), pp. 482-492. doi: 10.1108/08858620310492365.

Gunasekaran, A. et al. (2019) 'Agile Manufacturing: an Evolutionary Review of Practices', International Journal of Production Research, 57(15-16), pp. 5154-5174. doi:

10.1080/00207543.2018.1530478.

Haas, A., Snehota, I. and Corsaro, D. (2012) 'Creating Value in Business Relationships: The Role of Sales', Industrial Marketing Management. Elsevier Inc., 41(1), pp. 94-105. doi: 10.1016/j.indmarman.2011.11.004.

Halinen, A., Salmi, A. and Havila, V. (1999) 'From Dyadic Change to Changing Business Network: An Analytical Framework', Joumal of Management Studies, 36(November), pp. 779794.

Halinen, A., Törnroos, J.-Å. and Elo, M. (2013) 'Network Process Analysis: An Event-Based Approach to Study Business Network Dynamics', Industrial Marketing Management. Elsevier 
Inc., 42(8), pp. 1213-1222. doi: 10.1016/j.indmarman.2013.05.001.

Hartmann, N. N. and Lussier, B. (2020) 'Managing the Sales Force through the Unexpected Exogenous COVID-19 Crisis', Industrial Marketing Management. Elsevier, 88(April), pp. 101111. doi: 10.1016/j.indmarman.2020.05.005.

Havila, V. and Salmi, A. (2000) 'Spread of Change in Business Networks: An empirical Study of Mergers and Acquisitions in the Graphic Industry', Journal of Strategic Marketing, 8(2), pp. 105-119. doi: 10.1080/096525400346204.

Homburg, C., Müller, M. and Klarmann, M. (2011) 'When Should the Customer Really Be King? On the Optimum Level of Salesperson Customer Orientation in Sales Encounters', Journal of Marketing, 75(2), pp. 55-74. doi: 10.1509/jmkg.75.2.55.

Javalgi, R. (Raj) G., Granot, E. and Brashear Alejandro, T. G. (2011) 'Qualitative Methods in International Sales Research: Cross-Cultural Considerations', Journal of Personal Selling \& Sales Management, 31(2), pp. 157-170. doi: 10.2753/PSS0885-3134310204.

Johnson, J. S. and Sohi, R. S. (2017) 'Getting Business-to-business Salespeople to Implement Strategies Associated with Introducing New Products and Services', Industrial Marketing Management. Elsevier Inc., 62, pp. 137-149. doi: 10.1016/j.indmarman.2016.08.006.

Jones, E. et al. (2005) 'The Changing Environment of Selling and Sales Management', Journal of Personal Selling \& Sales Management, XXV(2), pp. 105-112.

Karjaluoto, H., Mustonen, N. and Ulkuniemi, P. (2015) 'The Role of Digital Channels in Industrial Marketing Communications', Journal of Business \& Industrial Marketing, 30(6), pp. 703-710. doi: 10.1108/JBIM-04-2013-0092.

Kelly, S. et al. (2020) 'Experienced Professionals and Doctoral Study: A Performative Agenda', Industrial Marketing Management. Elsevier, (February), pp. 0-1. doi: 10.1016/j.indmarman.2020.02.018.

Kowalkowski, C. et al. (2012) 'Service Infusion as Agile Incrementalism in Action', Journal of Business Research. Elsevier Inc., 65(6), pp. 765-772. doi: 10.1016/j.jbusres.2010.12.014.

Lacoste, S. and Blois, K. (2015) 'Suppliers' Power Relationships with Industrial Key Customers', Journal of Business \& Industrial Marketing, 30(5), pp. 562-571. doi: 10.1108/JBIM-03-2013-0057.

Lapadat, J. C. (2017) 'Ethics in Autoethnography and Collaborative Autoethnography', Qualitative Inquiry, 23(8), pp. 589-603. doi: 10.1177/1077800417704462.

Lashgari, M. et al. (2018) 'Adoption Strategies of Social Media in B2B Firms: a Multiple Case Study Approach', Journal of Business and Industrial Marketing, 33(5), pp. 730-743. doi: 10.1108/JBIM-10-2016-0242. 
Lassk, F. G. and Shepherd, C. D. (2013) 'Exploring the Relationship between Emotional Intelligence and Salesperson Creativity.', Journal of Personal Selling \& Sales Management, 33(1), pp. 25-37. doi: 10.2753/PSS0885-3134330103.

Lincoln, Y. and Guba, E. (1985) 'Establishing Trustworthiness', in Naturalistic Inquiry. Sage, pp. 289-331.

Lowe, S., Rod, M. and Hwang, K.-S. (2016) 'Understanding Structures and Practices of Meaning-making in Industrial Networks', Journal of Business \& Industrial Marketing, 31(4), pp. 531-542. doi: 10.1108/JBIM-05-2015-0097.

Matanda, T. and Ewing, M. T. (2012) 'The Process of Global Brand Strategy Development and Regional Implementation', International Journal of Research in Marketing. Elsevier B.V., 29(1), pp. 5-12. doi: 10.1016/j.ijresmar.2011.11.002.

Miller, C. C., Cardinal, L. B. and Glick, W. H. (1997) 'Retrospective Reports in Organizational Research: A Reexamination of Recent Evidence', Academy of Management Journal, 40(1), pp. 189-204. doi: 10.2307/257026.

Möller, K. and Halinen, A. (1999) 'Business Relationships and Networks: Managerial Challenge of Network Era', Industrial marketing management, 28, pp. 413-427.

Mora Cortez, R. and Johnston, W. J. (2020) 'The Coronavirus Crisis in B2B Settings: Crisis Uniqueness and Managerial Implications based on Social Exchange Theory', Industrial Marketing Management. Elsevier, 88(May), pp. 125-135. doi:

10.1016/j.indmarman.2020.05.004.

Mulki, J. P., Lassk, F. G. and Jaramillo, F. (2008) 'The Effect of Self-efficacy on Salesperson Work Overload and Pay Satisfaction', Journal of Personal Selling and Sales Management, 28(3), pp. 285-297. doi: 10.2753/PSS0885-3134280305.

Mullins, R., Agnihotri, R. and Hall, Z. (2020) 'The Ambidextrous Sales Force: Aligning Salesperson Polychronicity and Selling Contexts for Sales-Service Behaviors and Customer Value', Journal of Service Research, 23(1), pp. 33-52. doi: 10.1177/1094670519883344.

Odekerken-Schröder, G. et al. (2000) 'Moments of Sorrow and Joy', European Journal of Marketing, 34(1/2), pp. 107-125. doi: 10.1108/03090560010306232.

Ojha, D. et al. (2020) 'Managing Environmental Turbulence through Innovation Speed and Operational Flexibility in B2B Service Oraganizations', Journal of Business \& Industrial Marketing, ahead-of-p(ahead-of-print). doi: 10.1108/JBIM-01-2020-0026.

Palmatier, R. W. et al. (2013) 'Relationship Velocity: Toward A Theory of Relationship Dynamics’, Journal of Marketing, 77(1), pp. 13-30. doi: 10.1509/jm.11.0219.

Patton, M. Q. (2002) Qualitative Research and Evaluation Methods. Thousand Oaks: Sage publications. 
Piekkari, R., Plakoyiannaki, E. and Welch, C. (2010) “"Good” Case Research in Industrial Marketing: Insights from Research Practice', Industrial Marketing Management. Elsevier B.V., 39(1), pp. 109-117. doi: 10.1016/j.indmarman.2008.04.017.

Piercy, N. F. (2010) 'Evolution of strategic sales organizations in business-to-business marketing', Journal of Business \& Industrial Marketing, 25(5), pp. 349-359. doi: $10.1108 / 08858621011058115$.

Polkinghorne, D. E. (2007) 'Validity Issues in Narrative Research', Qualitative Inquiry, 13(4), pp. 471-486. doi: 10.1177/1077800406297670.

Prince, M. et al. (2016) 'An Integrative Framework of Buyer-Supplier Negative Relationship Quality and Dysfunctional Interfirm Conflict', Journal of Business-to-Business Marketing. Routledge, 23(3), pp. 221-234. doi: 10.1080/1051712X.2016.1215741.

Rajabi, R., Brashear-Alejandro, T. and Chelariu, C. (2018) 'Entrepreneurial Motivation as a Key Salesperson Competence: Trait Antecedents and Performance Consequences', Journal of Business and Industrial Marketing, 33(4), pp. 405-416. doi: 10.1108/JBIM-12-2016-0278.

Russ, F. A. et al. (1998) 'Exploring the Impact of Critical Sales Events.', Journal of Personal Selling \& Sales Management, 18(2), pp. 19-34.

Schmitz, C. and Ganesan, S. (2014) 'Managing Customer and Organizational Complexity in Sales Organizations', Journal of Marketing, 78(6), pp. 59-77. doi: 10.1509/jm.12.0296.

Schouten, J. W. and McAlexander, J. H. (1995) 'Subcultures of Consumption: An Ethnography of the New Bikers', Journal of Consumer Research, 22(1), p. 43. doi: 10.1086/209434.

Schurr, P. H., Hedaa, L. and Geersbro, J. (2008) 'Interaction Episodes as Engines of Relationship Change', Journal of Business Research, 61(8), pp. 877-884. doi: 10.1016/j.jbusres.2007.09.006.

Shankar, A., Elliott, R. and Goulding, C. (2001) 'Understanding Consumption: Contributions from a Narrative Perspective.', Journal of Marketing Management, 17, pp. 429-453.

Sharma, P. et al. (2020) 'Managing Uncertainty during a Global Pandemic: An International Business Perspective', Journal of Business Research. Elsevier, 116(May), pp. 188-192. doi: 10.1016/j.jbusres.2020.05.026.

Singh, R. and Das, G. (2013) 'The Impact of Job Satisfaction, Adaptive Selling Behaviors and Customer Orientation on Salesperson's Performance: Exploring the Moderating Role of Selling Experience', Journal of Business and Industrial Marketing, 28(7), pp. 554-564. doi: 10.1108/JBIM-04-2011-0121.

Spiro, R. L. and Weitz, B. a. (1990) 'Adaptive Selling: Conceptualization, and Nomological Validity’, Journal of Marketing Research, 27(1), pp. 61-69.

Steinle, C., Schiele, H. and Ernst, T. (2014) 'Information Asymmetries as Antecedents of 
Opportunism in Buyer-Supplier Relationships: Testing Principal-Agent Theory', Journal of Business-to-Business Marketing. Routledge, 21(2), pp. 123-140. doi:

10.1080/1051712X.2014.903457.

Strandvik, T., Holmlund, M. and Edvardsson, B. (2012) 'Customer Needing: a Challenge for the Seller Offering', Journal of Business \& Industrial Marketing, 27(2), pp. 132-141. doi: $10.1108 / 08858621211196994$.

Tähtinen, J. and Halinen, A. (2000) 'Ending Exchange Relationships : What do we Know about Them?', in 16th Annual IMP Conference.

Takhar-Lail, A. and Chitakunye, P. (2015) 'Reflexive Introspection: Methodological Insights from Four Ethnographic Studies', Journal of Business Research. Elsevier B.V., 68(11), pp. 2383-2394. doi: 10.1016/j.jbusres.2015.03.020.

Tarafdar, M. and Qrunfleh, S. (2017) 'Agile Supply Chain Strategy and Supply Chain Performance: Complementary Roles of Supply Chain Practices and Information Systems Capability for Agility', International Journal of Production Research, 55(4), pp. 925-938. doi: 10.1080/00207543.2016.1203079.

Terho, H. et al. (2012) ''It's almost like Taking the Sales out of Selling'-Towards a Conceptualization of Value-Based Selling in Business Markets', Industrial Marketing Management. Elsevier Inc., 41(1), pp. 174-185. doi: 10.1016/j.indmarman.2011.11.011.

Tidström, A. and Hagberg-Andersson, A. (2012) 'Critical Events in Time and Space when Cooperation Turns into Competition in Business Relationships', Industrial Marketing Management. Elsevier Inc., 41(2), pp. 333-343. doi: 10.1016/j.indmarman.2012.01.005.

Töytäri, P. et al. (2011) 'Bridging the Theory to Application Gap in Value-based Selling', Journal of Business and Industrial Marketing, 26(7), pp. 493-502. doi:

$10.1108 / 08858621111162299$.

Ulaga, W. and Loveland, J. M. (2014) 'Transitioning from Product to Service-led Growth in Manufacturing Firms: Emergent Challenges in Selecting and Managing the Industrial Sales Force', Industrial Marketing Management. Elsevier Inc., 43(1), pp. 113-125. doi: 10.1016/j.indmarman.2013.08.006.

Viio, P. and Nordin, F. (2017) 'Double-Loop Sales Adaptation: A Conceptual Model and an Empirical Investigation', Journal of Business-to-Business Marketing. Routledge, 24(2), pp. 123137. doi: 10.1080/1051712X.2017.1313673.

Visconti, L. M. (2010) 'Ethnographic Case Study (ECS): Abductive Modeling of Ethnography and Improving the Relevance in Business Marketing Research', Industrial Marketing Management. Elsevier Inc., 39(1), pp. 25-39. doi: 10.1016/j.indmarman.2008.04.019.

Wang, Y. et al. (2017) 'Social Media Capability in B2B Marketing: Toward a Definition and a Research Model', Journal of Business \& Industrial Marketing, 32(8), pp. 1125-1135. doi: 


\subsection{8/JBIM-10-2016-0250.}

Weitz, B. A., Sujan, H. and Sujan, M. (1986) 'Knowledge, Motivation, and Adaptive Behavior : A Framework for Improving Selling Effectiveness', Journal of Marketing, 50(4), pp. 174-191.

Woodside, A. G. and Wilson, E. J. (2003) 'Case Study Research Methods for Theory Building', Journal of Business \& Industrial Marketing, 18(6-7), pp. 493-508. doi:

$10.1108 / 08858620310492374$.

Yin, R. K. (2014) Case Study Research: Design and Methods. Los Angeles: Sage.

Yusuf, Y. Y., Sarhadi, M. and Gunasekaran, A. (1999) 'Agile Manufacturing: The Drivers, Concepts and Attributes', International Journal of Production Economics, 62, pp. 33-43.

Zhang, Z. and Sharifi, H. (2000) 'A Methodology for Achieving Agility in Manufacturing Organizations', International Journal of Operations \& Production Management, 20(4), pp. 496512. doi: 10.1108/01443570010314818.

Zhou, J., Mavondo, F. T. and Saunders, S. G. (2019) 'The Relationship between Marketing Agility and Financial Performance under Different Levels of Market Turbulence', Industrial Marketing Management. Elsevier, 83(November 2019), pp. 31-41. doi:

10.1016/j.indmarman.2018.11.008. 